\title{
First record of the Buff-breasted Sandpiper Tryngites subruficollis (Aves: Scolopacidae) in Santa Catarina state and an additional record for Paraná state, southern Brazil
}

\author{
Glauco Ubiratan Kohler ${ }^{1 *}$ \\ Leandro Corrêa ${ }^{1}$ \\ Ricardo Belmonte-Lopes ${ }^{2,3}$ \\ Marcos Ricardo Bornschein ${ }^{1,3}$ \\ Bianca Luiza Reinert ${ }^{3}$ \\ ${ }^{1}$ PPG em Ecologia e Conservação, Universidade Federal do Paraná \\ Centro Politécnico, Jardim das Américas, CEP 81531-990, Curitiba - PR, Brazil \\ ${ }^{2}$ PPG em Zoologia, Departamento de Zoologia, Universidade Federal do Paraná \\ ${ }^{3}$ Mater Natura - Instituto de Estudos Ambientais, Curitiba - PR, Brazil \\ *Corresponding author \\ chloroceryle@gmail.com
}

Submetido em 08/11/2009

Aceito para publicação em 14/03/2010

\begin{abstract}
Resumo
Primeiro registro do maçarico-acanelado Tryngites subruficollis (Aves: Scolopacidae) em Santa Catarina e registro adicional para o Paraná, sul do Brasil. Em 17 de outubro de 1997, observamos um indivíduo do maçarico-acanelado Tryngites subruficollis em uma praia arenosa em Praia Deserta, Barra do Superagui, Parque Nacional de Superagui, município de Guaraqueçaba, litoral norte do Paraná. Os únicos registros prévios para o litoral do estado datam de 1993. Em 10 de setembro de 2009, observamos nove indivíduos da espécie em um arrozal no distrito de Joáia, município de Tijucas, litoral central de Santa Catarina, sul do Brasil. Este é o primeiro registro para o estado. O escasso número de registros nesses estados pode estar relacionado com raridade regional da espécie, ausência de trabalhos de campo em hábitat e época apropriados e/ou confusão de identificação com outros maçaricos.
\end{abstract}

Unitermos: arrozais, litoral sul do Brasil, migração, Tryngites subruficollis

\section{Abstract}

On 17 October 1997 we observed one individual of Buff-breasted Sandpiper Tryngites subruficollis on a beach of Praia Deserta, Barra do Superagui, Superagui National Park, municipality of Guaraqueçaba, on the northern coast of Paraná. The only previous records for the Paraná coast dates from 1993. On 10 September 2009 we observed nine individuals of the species in a rice field in Joáia district, municipality of Tijucas, central coast of Santa Catarina state, southern Brazil. This is the first record for this state. The scarce number of records in these states may be related to regional rarity of the species, absence of field work in the proper habitat and time of year, and/or misidentification with other sandpipers.

Key words: Buff-breasted Sandpiper, migration, rice fields, southern Brazilian coast 
The Buff-breasted Sandpiper Tryngites subruficollis breeds from June to August on the Arctic coast, on well drained tundra with tussocks and scant vegetation (Hayman et al., 1986; Lanctot and Weatherhead, 1997; BirdLife International, 2008). The species migrates to South America, where it is found from August to March (Hayman et al., 1986; Lanctot et al., 2002). The most important areas for the wintering birds are grasslands and pampa from a narrow coastal area of southern Brazil (Rio Grande do Sul state), Uruguay, and Argentina (Buenos Aires province) (Lanctot et al., 2002). Agricultural fields, sod farms, mowed hayfields, secondary grasslands with short grasses and intensively grazed pasturelands composed the main terrestrial habitats occupied by this species (Lanctot et al., 2002; Isacch and Martínez, 2003; Jorgensen, 2007; McCarty et al., 2009).

According to BirdLife International (2008), the Buff-breasted Sandpiper had its global population estimated in hundreds of thousands to millions during the $1890 \mathrm{~s}-1900 \mathrm{~s}$, but it declined nearly to extinction in the early 1920 s due to hunting. Today its global population is estimated at $16,000-84,000$ individuals. However, the number of estimated individuals is declining again and the species is considered a Near Threatened species at global level (IUCN, 2009). In Brazil, the Buff-breasted Sandpiper has been recorded in the states of Acre, Amazonas, Maranhão, Rondônia, Mato Grosso, São Paulo, Paraná and Rio Grande do Sul (Pinto, 1964; Belton, 1994; Bornschein et al., 1997; Sick, 1997; Lanctot et al., 2002; Bencke et al., 2003). No sufficient data on its regional status in Brazil are available, except in Rio Grande do Sul state, where it is considered vulnerable (Bencke et al. 2003).

In southern Brazil there are several records of the species in Rio Grande do Sul between August and April (Belton, 1994; Lanctot et al., 2002; Bencke et al., 2003), and a few from Paraná. On the central coast of Paraná state, individuals were observed (two were collected) in two localities from September to November 1993 (Bornschein et al., 1997), and two other individuals were observed inland, in Curitiba municipality, in October 2001 (Straube et al., 2009).

On 17 October 1997, M. R. B. and B. L. R. observed one individual of the Buff-breasted Sandpiper on Praia

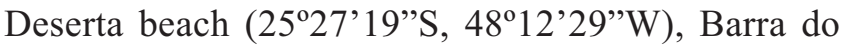
Superagui, Superagui National Park, municipality of Guaraqueçaba, on the northern coast of Paraná. On the rainy morning of 10 September 2009, we observed (except B. L. R.) nine individuals in a rice field in Joáia district (2716'29'S, 48³9'57'W; 10m a.s.1.; Figure 1), municipality of Tijucas, in the lowlands of the central coast of Santa Catarina. This is the first record for this state. The rice field had no plant cover, the soil being recently ploughed and with a thin water layer partially covering it (Figure 1). On this occasion, birds were in a mixed-species flock with White-rumped Sandpiper Calidris fuscicollis (about 10 individuals), Whitefaced Ibis Plegadis chihi (243 individuals), Southern Lapwing Vanellus chilensis (22 individuals), Pluvialis sp. (six individuals), Lesser Yellowlegs Tringa flavipes (five individuals), and White-backed Stilt Himantopus melanurus (two individuals).

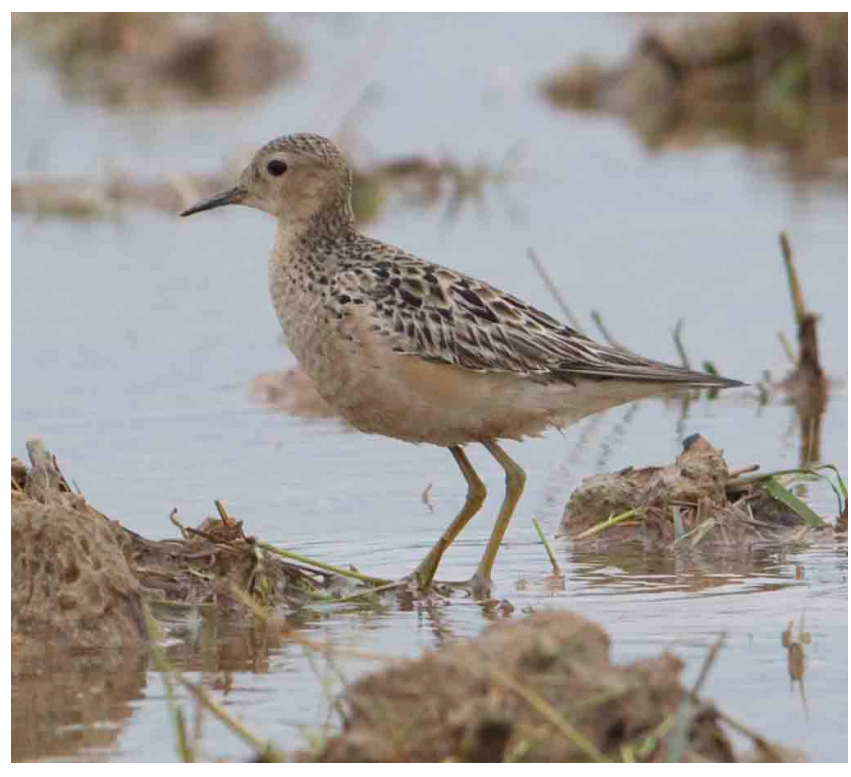

FIGURE 1: Buff-breasted Sandpiper Tryngites subruficollis observed on 10 September 2009 in a rice field in Joáia district, in the municipality of Tijucas, on the central coast of Santa Catarina state, southern Brazil (Photo by Ricardo Belmonte-Lopes).

On the coasts of Paraná and Santa Catarina states, rice plantations are abundant and have been increasing in recent years over areas formerly occupied by lowland forests and pastures. This new landscape provides a new habitat for waders. However, the occurrence of these birds in rice fields coincides with the period that 
the paddies are sprayed with pesticides and herbicides, potentially exposing birds to contamination (Lanctot et al., 2002). The presence of the Buff-breasted Sandpiper in Santa Catarina state was expected based on records from neighboring Rio Grande do Sul and Paraná states. The dates of the new records of the species presented here are in accordance with its migration season in southern Brazil. The scarce number of records in Paraná and Santa Catarina may be related to regional rarity of the species, absence of field work in the proper habitat and time of the year, and/or misidentification with other sandpipers.

\section{Acknowledgments}

The Fundação O Boticário de Proteção à Natureza funded the field work in Santa Catarina through one project $(0778 / 20081)$ executed by Mater Natura Instituto de Estudos Ambientais. The Instituto Brasileiro do Meio Ambiente e dos Recursos Naturais Renováveis (IBAMA) authorized the research on Superagui National Park to B. L. R. and M. R. B. Rafael A. Dias and two anonymous referees critically reviewed the manuscript. Christoph Hrdina and Kitty Harvill reviewed the English language.

\section{References}

Belton, W. 1994. Aves do Rio Grande do Sul: distribuição e biologia. Unisinos, São Leopoldo, Brazil, 584pp.

Bencke, G. A.; Fontana, C. S.; Dias, R. A.; Maurício, G. N.; Mähler Jr, J. K. F. 2003. Aves. In: Fontana, C. S.; Bencke, G. A. \& Reis, R. E. (Eds). Livro vermelho da fauna ameaçada de extinção no Rio Grande do Sul. EDIPUCRS, Porto Alegre, Brazil, p.189-479.
BirdLife International. 2008. Tryngites subruficollis. In: IUCN 2009. IUCN red list of threatened species. Version 2009.1. Available at $<$ www.iucnredlist.org $>$. Accessed on 16 September 2009.

Bornschein, M. R.; Reinert, B. L.; Pichorim, M. 1997. Notas sobre algumas aves novas ou pouco conhecidas no sul do Brasil. Ararajuba, 5 (1): 53-59.

Hayman, P.; Marchant J.; Prater T. 1986. Shorebirds: An identification guide. Houghton Mifflin Company, Boston, USA, 412pp.

Isacch, J. P.; Martínez, M. M. 2003. Habitat use by non-breeding shorebirds in flooding pampas grasslands of Argentina. Waterbirds, 26 (4): 494-500.

IUCN. 2009. IUCN red list of threatened species. Version 2009.1. Available at $<w w w . i u c n r e d l i s t . o r g>$. Accessed on 17 September 2009.

Jorgensen, J. G.; Mccarty, J. P.; Wolfenbarger, L. L. 2007. Landscape and habitat variables affecting Buff-breasted Sandpiper Tryngites subruficollis distribution during migratory stopover in the Rainwater Basin, Nebraska, USA. Wader Study Group Bulletin, 112: 45-51.

Lanctot, R. B.; Blanco, D. E.; Dias, R. A.; Isacch, J. P.; Gill, V. A. Almeida, J. B.; Delhey, K.; Petracci, P. F.; Bencke, G. A.; Balbueno R. A. 2002. Conservation status of the Buff-breasted Sandpiper: Historic and contemporary distribution and abundance in South America. Wilson Bulletin, 114 (1): 44-72.

Lanctot, R. B.; Weatherhead, P. J. 1997. Ephemeral lekking behavior in the buff-breasted sandpiper, Tryngites subruficollis. Behavioral Ecology, 8 (3): 268-278.

McCarty, J. P.; Jorgensen, J. G.; Wolfenbarger, L. L. 2009. Behavior of Buff-Breasted Sandpipers (Tryngites subruficollis) during migratory stopover in agricultural fields. Plos One, 4 (11): e8000.

Pinto, O. M. O. 1964. Ornitologia brasiliense. Primeiro volume: parte introdutória e famílias Rheidae a Cuculidae. Departamento de Zoologia, Universidade de São Paulo, São Paulo, Brazil, 182pp.

Sick, H. 1997 Ornitologia brasileira. Nova Fronteira, Rio de Janeiro, Brazil, 862pp.

Straube, F. C.; Carrano, E.; Santos, R. E. F.; Scherer-Neto, P.; Ribas, C. F.; Meijer, A. A. R.; Vallejos, M. A. V.; Lanzer, M.; KlemannJunior, L.; Aurélio-Silva, M.; Urben-Filho, A.; Arzua, M.; Lima, A. M. X.; Sobânia, R. L. M.; Deconto, L. R.; Bispo, A. A.; Jesus, S.; Abilhoa, V. 2009. Aves de Curitiba. Hori Consultoria, Curitiba, Brazil, 280pp. 